\title{
"18 is not a magic number": Faculty Reflections on Student Development Theories in Creating Inclusive Classrooms
}

\author{
Paul S. Hengesteg ${ }^{1}$ D $\cdot$ Laura Bestler $^{1} \cdot$ Sara B. Marcketti $^{1}$
}

Accepted: 19 April 2021 / Published online: 29 May 2021

(c) The Author(s), under exclusive licence to Springer Nature B.V. 2021

\begin{abstract}
Inclusive classroom training typically focuses on course design, teaching strategies, and evaluation practices girded in best teaching practices. Our university has hosted inclusive classroom training for six years, but just recently began providing mandatory training in each of the university's academic departments for teaching faculty (including term, tenure-track, tenured, and adjunct professors). The newness and relevancy of student development theories to faculty proved worthy of increased attention by our Center for Excellence in Learning and Teaching. Using qualitative assessment data from our institution's mandatory Inclusive Classroom Annual Training for faculty, we present findings that illustrate how instructors would benefit from cursory information on student development theories. Faculty reflections focused around three themes. First, it is essential for faculty to humanize teaching and learning by remembering to teach students and not just course content. Second, faculty could connect their new knowledge of student development theories to their pedagogies and specifically how it can promote inclusive classroom environments. Finally, participants shared vulnerabilities by interpreting their past, present, and future teaching through a lens of student development theories. Also provided are recommendations to enhance teaching development for faculty, teaching and learning centers, and student affairs educators centered on the importance of student development theories.
\end{abstract}

Keywords Assessment · Faculty · Faculty development - Student development · Inclusive classroom $\cdot$ Teaching and learning

Like many college campuses, Iowa State University experiences acts and displays of hate, usually in the form of either racism or homophobia (Campus climate incidents, n.d.). In some cases, the perpetrators of these actions remain unknown. During the 2019 fall semester, a student group on campus insisted that university administration

Paul S. Hengesteg

paulh@iastate.edu

1 Center for Excellence in Learning and Teaching, Iowa State University, Ames, IA, USA 
take a more proactive role in eliminating exclusion and discrimination on campus. In response to and aligning with the student demands, university leadership mandated that all teaching faculty participate in the Inclusive Classroom Annual Training led by the Center for Excellence in Learning and Teaching (CELT). In January 2020, CELT facilitated the first year of training, reaching about half of all departments, and then extending to reach all 56 departments at the end of fall semester 2020 (extended due to disruptions caused by Covid-19). CELT will launch the second year of training in the fall of 2021 with each year of training focusing on a distinct component of inclusive teaching from foundational teaching approaches in year one to a focus on our students in year two.

In the present manuscript, we explore the faculty's reflections during the inaugural mandatory training, with specific attention to one of the learning modules that introduced student development theories as a key component of inclusive pedagogy. Within the paper is a section that describes our training, our institution, and our faculty for readers' context. Although an analysis of faculty perceptions of student development theories was not our original goal for data analysis, the faculty reflections were so compelling that we believed the lack of knowledge and the perspectives gained through these reflections warranted sharing with a broader audience. Our findings suggest that student development theories were broadly new information for faculty and allowed our faculty to think about students in more nuanced ways - as complex, developing adults with individual contexts that influence their classroom engagement and success. Our findings can be valuable for other centers of teaching and learning who also want to advance inclusive teaching excellence. We conclude our paper with suggestions to more intentionally involve student development theory in teaching praxis.

\section{The Conundrum}

Faculty (encompassing the variety of instructional ranks and appointments) must balance multiple demands of their profession, including expectations for teaching excellence, quality and quantity of scholarship, and institutional and disciplinary service involvement. Often, institutions support new faculty's research trajectories through start-up funding for laboratories, grant-writing workshops, and course releases within the first one to three years of beginning a tenure-track position. However, there is less systemized support for teaching development and often few resources to support the development of term faculty who maintain high teaching loads. Indeed, doctoral education's socializing process focuses on developing subject matter experts (Gardner, 2008; Mendoza \& Gardner, 2010), often at the expense of teaching and pedagogical training. Even if graduate students and new faculty members interact with the college or university teaching and learning center, these interactions often occur as "add-ons" to the academic departments' professional development provided at the college-level. Further, centers provide essential but voluntary and formative information and suggestions, rather than compulsory and summative experiences (Haras et al., 2017). To restate this idea, engaging with the teaching and learning center is often optional and can be overlooked. 
As a result of the limited attention to teaching, many faculty may rely on their own experiences as students or in limited interactions with fellow departmental faculty when going about their instruction. Without study and introspection, faculty can fall prey to "doing what worked for them" and carrying their own biases and misperceptions of effective teaching and student learning into the classroom (Starck et al., 2020). This approach is limiting and potentially harmful when considering the demographic changes that have occurred within higher education.

Today's current college students and those to come, born between 1996 and 2012, represent the most diverse and inclusive generation in United States history. National and international events such as technological advancement, a volatile economy, and social justice movements have profoundly influenced and informed this generation's attitudes and behaviors. Additionally, after 2025, there will be fewer prospective high-school graduates, the result of a decline in birthrates during and after the Great Recession of 2008. Frequently referred to as the enrollment cliff, the viability and sustainability of programs, departments, and higher education institutions are threatened, and teaching effectively becomes more critical than ever before. It is vital that faculty, regardless of the institution, acknowledge that the idea of a "typical college student" is changing. Our universities provide the learning environments, both in and outside of the classroom, where students move from adolescence to adulthood to prepare for the workforce or advanced studies (Selingo, 2018). As such, it is more important than ever before, for faculty to concentrate their teaching efforts on evidence-based teaching practice that enhance learning for all students. In other words, faculty must continually reflect on what they think they know about their students.

Given the varied demands faced by faculty, we acknowledge that it may feel overwhelming to also learn and apply student development theories. However, following a review of the data gathered, we believe that Inclusive Classroom Training cannot occur without a solid underpinning of student development theory. Without the foundational knowledge that students are not magically fully developed adults simply by virtue of the fact they matriculated across our gates after high school, teaching strategies will become just activities and tactics rather than an intentional dimension of designing inclusive classroom environments. It then becomes vital to understand the ways that college students are continually developing their cognitive, moral, social, psychological, emerging-adult selves - both in and outside of the classroom. We do not imply that students should not be held accountable when they misstep; rather, we want to highlight student developments' iterative nature. In the next section, we describe some essential contexts for understanding for our readers, including descriptions of our institution, our students, our faculty, and the Inclusive Classroom Annual Training itself.

\section{Context: Site and Training}

We utilized faculty responses $(n=1,383)$ from the first year of a mandatory Inclusive Classroom Annual Training at our Midwestern, land grant, doctoral-granting institution. Our institution is a predominantly and historically White institution $(\mathrm{P} / \mathrm{HWI})$, with an undergraduate student body $(n=28,294)$ that is about $57 \%$ 
male-identifying. About $21 \%$ of our students identify as first-generation. More than half of our students come from within the state, and around $4 \%$ of students are international students. Finally, approximately $95 \%$ of our students are 24 years old or younger, meaning they fit into what might be considered traditional college-aged students (Iowa State University, 2021).

Using our institutional Fact Book (Iowa State University, 2020), we compiled Table 1 to describe our 1,858 faculty. Our faculty predominantly identified as White and male, and most are $20+$ years older than our students. Although analyzing our faculty profile is not our goal, when observing the structural diversity of our faculty, we recognize that gender and race inequities exist within our faculty body. Even with CELT's efforts to promote inclusive classrooms, these disparities present a challenge when our underrepresented students do not see people who look like them in the front of the classroom.

\section{The Inclusive Classroom Training}

The first year of training consisted of two major components: online learning modules and a CELT-led departmental synchronous session (face-to-face or online). We used the flipped-classroom approach to engage faculty through active learning techniques (e.g., discussions, problem-based learning, group work, etc.) rather than through a lecture-based synchronous experience. CELT delivered foundational content about the inclusive classroom as three self-paced learning modules in Canvas, our learning management system. Each module provided learning objectives,

Table 1 Faculty Profile

\begin{tabular}{|c|c|c|c|}
\hline & $\begin{array}{l}\text { Tenured } \\
n=981(52.8 \%)\end{array}$ & $\begin{array}{l}\text { Tenure-Eligible } \\
n=298(16.0 \%)\end{array}$ & $\begin{array}{l}\text { Term Faculty } \\
n=579(31.1 \%)\end{array}$ \\
\hline \multirow[t]{3}{*}{ Gender } & Men $58.6 \%$ & Men $60.7 \%$ & Men $44.4 \%$ \\
\hline & Women $31.3 \%$ & Women $38.9 \%$ & Women $55.6 \%$ \\
\hline & Unkwn/Missing $0.1 \%$ & Unkwn/Missing $0.3 \%$ & \\
\hline \multirow[t]{6}{*}{ Race } & White $73.0 \%$ & White $58.7 \%$ & White $80.8 \%$ \\
\hline & Black $2.3 \%$ & Black 2.3\% & Black 2.6\% \\
\hline & Latinx 3.3 & Latinx $4.0 \%$ & Latinx $3.8 \%$ \\
\hline & Asian $19.3 \%$ & Asian $27.2 \%$ & Asian $6.9 \%$ \\
\hline & International $0.9 \%$ & International $15.1 \%$ & International $4.7 \%$ \\
\hline & All other $1.3 \%$ & All other $2.7 \%$ & All other $11.9 \%$ \\
\hline \multirow[t]{6}{*}{ Age } & $21-300.0 \%$ & $21-305.0 \%$ & $21-303.5 \%$ \\
\hline & $31-407.7 \%$ & $31-4064.1 \%$ & $31-4027.8 \%$ \\
\hline & $41-5032.3 \%$ & $41-5023.5 \%$ & $41-5026.4 \%$ \\
\hline & $51-6028.5 \%$ & $51-607.0 \%$ & $51-6022.5 \%$ \\
\hline & $61-646.2 \%$ & $61-640.3 \%$ & $61-649.8 \%$ \\
\hline & $65+18.2 \%$ & $65+0.0 \%$ & $65+10.0 \%$ \\
\hline
\end{tabular}

"All other" racial category includes those with multiple racial identities. 
content (e.g., brief readings, videos), and a self-reflection component. Our goal with the modules was to provide foundational information as to why inclusive teaching is important. The first module connected inclusive classrooms to the university's land grant mission. The second module focused on implicit biases or unconscious attitudes, reactions, and stereotypes that affect behavior and understanding (Kirwan Institute for the Study of Race \& Ethnicity, 2015). This module connected one's teaching with identity, privilege, and bias. The third module, the focus of this manuscript, focused on student development theories and how connected they are to student learning. As part of this module, faculty read a chapter infused with student development theories (Ambrose et al., 2010). This module concluded with tangible action items developed by CELT staff informed from existing literature that faculty could incorporate into their teaching to move the needle towards a more inclusive environment.

Each academic department scheduled their synchronous program, often during a regular faculty meeting, facilitated by a CELT staff member. After solidifying planning, CELT shared with the unit leadership and departmental liaison the session outline, slide presentation, and strategies to create an inclusive classroom handout (Appendix A). (The department liaison was a faculty member identified by the department chair to help facilitate the training who received $\$ 500$ in professional development stipend from the Senior Vice President and Provost Office). Before the synchronous program, we asked the departmental liaison to identify one or two inclusive teaching practices relevant to their subject area that they could share during the training. For example, one strategy within the CELT handout was to "ensure images and illustrations are representative of diverse appearances (e.g., genders, abilities, ages, etc.)." The apparel program departmental facilitator shared that they strive to include images of individuals representing multiple sizes and ages (compared to popular media's traditional examples of youthful, very thin fashion models) to demonstrate the wide range of people interacting with the apparel industry.

During the one-hour synchronous program, CELT faculty and staff presented an active-learning style presentation with a lecture component, videos of students from our university discussing when "someone made them feel less than" and led three small group discussions. The discussions centered around a created handout focused on: course design, teaching strategies, and evaluation practices (see Appendix A). Throughout the presentation, the CELT facilitator asked the departmental liaison to share discipline-related examples on how they or their colleagues infused inclusion into the learning environment. The training objectives focused on faculty recognition of the importance of teaching inclusively and identifying a course-specific improvement for their classrooms.

\section{Student Development Theories}

The purpose of student development theories is to allow educators to understand where students might "be" in their development journey and then determine ways to move students into further realms of growth or maturity. They are valuable in higher education because, "Knowledge of student development theory enables student 
affairs professionals to identify and address student needs, design programs, develop policies, and create healthy college environments that encourage positive growth in students" (Evans et al., 2010, p. 7; Long, 2012). Much of the early disciplinary scholarship traced its roots to psychology, human development, and sociology. Student development theories are malleable, meaning they shift over time to accommodate new ways of thinking. To briefly describe the wide range of student development theories within the literature, we rely on Jones and Stewart (2016), who borrowed the wave metaphor from feminism to group the scholarship. The works cited in this section are a cross-section of examples readers could choose to investigate independently and are not intended to be an exhaustive list of theories.

Foundational theories emerged in the 1950s and 1960s and continue to be taught in Higher Education Student Affairs (HESA) graduate courses (Harris, 2020). Among these theories are Perry's $(1968,1981)$ Theory of Intellectual and Ethical Development, Chickering's (1969, 1993) Theory of Identity Development, Kohlberg's (1976) Theory of Moral Development, and Sanford's (1966) foundational work about the balance of challenge and support for college students (Jones \& Stewart, 2016). These theories, critiqued by contemporary scholars for relying on epistemic notions of colonialism and positivism, attempt to project monolithic understandings of populations and not considering interlocking systems of privilege and oppression (Abes, 2016; Nicolazzo, 2016). Indeed, white men authored all theories listed in this paragraph, with most of the research participants also being white. Nicolazzo noted that many of these theories sought to "normalize" (n.p.) students and their development, which can be dangerous to those from marginalized groups. Nonetheless, being aware of these foundational theories helps inform the scholarly, generational evolution of student affairs (Harris, 2020).

The second wave of student development theories focused on "diverse populations, social identities, and holistic theories" (Jones \& Stewart, 2016, p. 18) to account for college campuses' growing diversity. The literature saw the emergence of theories that focused on ethnic identity development (Phinney, 1993) and Black students' development (Cross, 1971, 1978; Helms, 1993). Belenky et al. (1986) advanced scholarship entitled "Women's Ways of Knowing: The Development of Self, Voice, and Mind" to illustrate that men and women develop differently. Cass (1979) offered up her stage-based model of Homosexual Identity Formation, and Klein et al. (1985) developed a multi-dimensional and dynamic understanding of sexual orientation. These scholars provided foundations for future scholars and their work, as is seen in the third wave. It is also important to note that the theories mentioned here provided a singular focus on a particular identity. Scholars such as Jones and McEwen (2000) created the Model of Multiple Dimensions of Identity to remind audiences that students may also have to navigate the intersections of multiple marginalized identities simultaneously.

CELT looked to more recent theories such as the third wave, which "appl[ied] critical and poststructural perspectives to an understanding of student development" (Jones \& Stewart, 2016, p. 18). These perspectives seek to upend traditional notions of "knowledge" by examining how power influences knowledge-having and knowledge-making. Moreover, these perspectives eschew positivist "objectivity" in research by acknowledging that identity is key to a student's (and researcher's) 
experience (Creswell, 2014). Theorists such as Delgado and Stefancic (2001), who brought us Critical Race Theory (CRT), indicated that CRT takes up many of the same perspectives that civil rights discourses do. Also, the theory extends to consider how "broader perspectives that include economics, history, context, group- and self-interest, and even feelings and the unconscious" (2001, p. 3) affect people of color. Borne in this same wave are feminist and gender theories (Butler, 1990/2018, 2004; Haraway, 1985/2013), likewise Queer Theory (Jagose, 1996; Talburt, 2011), and theories of disability (McRuer, 2006; Titchosky, 2011). When amassed, these theories purposefully seek to impact social justice outcomes by inviting audiences to rethink what they know. Many of these scholars aim to interrogate the notion of "identity" as stable in favor of more complex, dynamic understandings of identity and the human experience (Jones \& Stewart, 2016).

Students are enrolled in our colleges and universities to learn. Teaching future generations is of vital importance to self and societal improvement. Just as a student's classroom learning impacts their skills and abilities to impact the world, the world's experiences impact how - and sometimes even, if - a student learns. This inter-relational dynamic is the work of student development theory that has been vitally important to generations of educators as they engage with students in empirically grounded ways. Being mindful of the development happening among college students will aid an instructor's efforts to teach inclusively. This paper fills a literature gap that focuses on faculty's perceived usefulness of student development theory in their teaching. Our guiding research question was: What key take-aways do faculty come away with by exposure to student development theories as part of their inclusive teaching journey?

\section{Methods}

At the end of each online module, participants reflected on their learning within that module by answering an open-ended question. The question prompts provided freestyle writing to gather rich, qualitative data. Because this was the inaugural training, we wanted to hear more from faculty than responses a Likert-scale questions might provide. We also wanted to send the message that reflection on teaching is critical, and believed this feedback style would foster that goal. In this training, we elected not to collect any baseline knowledge or experience from the faculty, mainly since the need for the training was evident from the student demands for inclusive classroom training.

All in-module reflections were downloaded, organized, and divided by institutional college but were otherwise anonymous. The authors saved the documents with the responses to a safe, cloud-based storage folder with limited access. Attributions to the reflective comment, LAS57, for example, represents the $57^{\text {th }}$ response from that college. At our institution, we have eight academic departments that are housed in multiple colleges. One example of such a department would be Agriculture and Biosystems Engineering, which is connected with both the College of Engineering and the College of Agriculture and Life Sciences. Rather than "picking" which college to assign the data to, we decided that these data should be their own category. The table below (Table 2) provides the key for understanding our collegenaming shorthand. 
Table 2 College abbreviations

\begin{tabular}{ll}
\hline Abbreviation & College \\
\hline CALS & College of Agriculture and Life Sciences \\
DSN & College of Design \\
ENGR & College of Engineering \\
HSCI & College of Human Sciences \\
BUS & College of Business \\
LAS & College of Liberal Arts and Sciences \\
VMED & College of Veterinary Medicine \\
INTR & Interdisciplinary departments that span two colleges \\
\hline
\end{tabular}

Reflections were read with the accumulated data, noting themes and patterns, known as initial or open coding (Saldaña, 2016). In the second round of coding (i.e., axial coding; Saldaña, 2016), these quotes were gathered into a new document for review to articulate the three emergent themes discussed below. To ensure the findings' trustworthiness, the authors reviewed the coding document and upon reflecting on their own experiences developing and leading the training, confirmed the major findings. Finally, we shared these findings with departmental liaisons who also confirmed these themes as being part of their experience with the training.

\section{Findings}

Evaluation of the Inclusive Classroom Annual Training data suggests that student development theories were new to the majority of faculty's understanding of teaching and learning. Faculty used terms such as "enlightening," "insightful," or "revealing" to describe the assigned reading. One faculty commented that information on student development theories gave them brand new perspectives about their students, and noted the information "gave me more concrete knowledge than how I had thought about differences between Freshmen and Seniors before (which was more general and I attributed it to maturity and adjusting to life in college)" (INTR32). Even for those familiar with student development theories, particularly those teaching within education, human development and family studies, and sociology departments, there was (re)confirmation of the importance of these ideas. For example, one instructor stated they were able to, "reaffirm that some of the strategies that I use instinctively in my classroom to enhance inclusivity are among those identified as best practices. I was also able to learn new practices that I have not regularly employed" (INTR91).

Following coding of each of the reflection statements, three key themes appeared. First, it is essential for faculty to humanize teaching and learning by remembering to teach students and not just course content. Second, faculty could connect their new knowledge of student development theories to their pedagogies and specifically how it can promote inclusive classroom environments. Third, the 
participants shared vulnerabilities by interpreting their past, present, and future teaching through a lens of student development.

\section{Teach Students, Not Just the Material}

A strong thread in the faculty responses was the need to recalibrate instructional philosophy to "teach students, not material" (ENGR61). Faculty found it helpful to think about their students holistically - as complex beings with many life experiences that can impact their learning while in college. One professor who linked the holistic approach to their work in the College of Veterinary Medicine stated, "Just as we are focused on treating patients rather than symptoms in our hospital, in the classroom we will have more success if we teach students rather than focusing entirely on content" (VMED14). Another professor in the College of Business added:

This material will make me more aware of my students as individual human beings. As the reading stated, sometimes we get so caught up in teaching content that we forget to teach our students. That point really resonated with me (BUS42).

A colleague offered similar comments and connected the concept to better student learning:

I found the ideas of "teaching to the student" and "teaching to the course content" interesting from a holistic learning standpoint. Also, this coupled with the discussion of the developmental stage of college students. If the climate is not [positive] then high level of learning for ALL students is not probable (BUS114).

We found these comments and others to stand out because they serve as a good, albeit unfortunate, reminder that faculty might focus exclusively on the course's content rather than the students within their classes.

Student development theories often (though not uniformly) focus on a person's progression from one, presumably more complex or advanced, stage/phase to another. Faculty responded to the stage-like nature of developmental theory and reflected on their recognition of student cognitive growth:

The progression of intellectual development outlined in [the article] was new information and very interesting to me. I feel that I have observed the described stages of intellectual development, but have never had them outlined like this. I believe that it will be helpful to be aware that students may be more or less open to different ideas and to understand that their degree of openness may be representative of their stage of intellectual development. Without this background knowledge, it could be easy to assume that a student is merely stubborn or naive (CALS42). 
This person identified a risk of being unfamiliar with student development theory, which implies a misguided understanding of students, rather than recognizing that scholars have written about how students change during the college years. Another member of the faculty agreed with the notions of students as evolving:

One piece of information that resonated with me is that college students are still in a developing stage of their lives. In my first semester of teaching, I made a wrong [assumption] (sic) that college students should know what they need to do because they are adults. In the second semester, I realized that 18 is not a magic number. They don't just suddenly become an adult when they turned 18. They still need our help to continue their social, emotional and intellectual development (BUS141).

In this example, a unique tension arose that is commonly understood by education and human development scholars, that traditional-aged college students (i.e., those aged 18-24) simultaneously are and are not adults. Emerging Adulthood Theory (Arnett, 2000) cautions that many college students do not perceive themselves as adults. However, society assumes them to be, creating tension between perceptions and reality of thoughts and behaviors.

Faculty respondents began to see their classroom environments as more than monolithic, singular-use spaces that focus only on knowledge within their respective disciplines. Indeed, specific skills and disciplinary expertise are vital, but as one faculty indicated, "We need to look at our classrooms not only as intellectual but also as social and emotional environments" (LAS178). As faculty began to connect with a compassionate approach to their teaching rather than a pedagogy that focuses solely on content, they understood the benefits of doing so. Meyers et al. (2019) consider this teaching with empathy, whereby instructors in higher education "work to deeply understand students' personal and social situations, feel caring and concern in response to students' positive and negative emotions, and communicate their understanding and caring to students through their behavior" (p. 161). Faculty responses reflected how holistically thinking about students affords opportunities to connect their pedagogies with the university's desire for more inclusive classrooms. Although we have not yet followed-up with faculty to determine implementation, it appears there is a willingness or desire to approach their teaching with a more holistic-student approach.

\section{Connections: Student Development Theories, Pedagogies, and Inclusive Classrooms}

Student development theorists propose that there are ways to promote students' growth, and that there is a need to bring ideas from theory-to-practice (Reason \& Kimball, 2012). Faculty responding to the module indicated through their reflections that they began to see "student development as part of pedagogy in teaching" (LAS16). In other words, "meeting students where they are" (common parlance for those in student affairs) or first listening, recognizing, and validating students' experiences are paramount to effective teaching and learning practices. 
Many respondents acknowledged that helping students intellectually also means helping them in other aspects of their lives that could make learning challenging. A representative comment along these lines from an Engineering professor noted, "college students are undergoing momentous changes in their life. It is important to recognize the complex set of social, emotional, and intellectual challenges that college students face" (ENGR7).

Faculty respondents described how student development theories could be valuable when exploring content that is dissonant with students' past experiences and epistemologies:

The new piece of information that stood out most to me...was about the breadth and depth of student development. Specifically, how students comprehend information differently during college. For instance, some students think "black and white" and may have problems transitioning to ambiguous discussions which do not result in just one answer (LAS222).

Another professor from the same college shared a similar sentiment:

It was eye-opening to think about different stages in the development of people from childhood through young adulthood (college years) and into older adults. I find it promising and feel optimistic knowing that exposure to hard topics and training on critical thinking and the view of others can help our college students (undergraduates) develop more mature and better-informed attitudes about race, ethnicity, empathy, and inclusion in general (LAS5).

This professor seems excited about how developmental models can help develop critical thinking in the classroom around social justice issues. While referring to Perry's $(1968,1981)$ schema, this professor connected development to their discipline of teacher preparation:

I had not thought about the intersection of developing autonomy and establishing identity with the college years - specifically, the movement from duality: right/wrong stances to relativism and commitment: the move from unexamined to more nuanced views. This timing coincides exactly with our undergrads encountering our teacher preparation instruction that specifically pushes them to develop more nuanced views of things like race, culture, what you learned in history class, and what books you loved as a child. Add to this the fact that most of our students are young white women (and some white men) from rural settings and even urban settings that lack diversity, and I can understand why some of them push back and have difficulty with the challenging expectations we have for them. This is not to say we need to change our approaches to bow to white fragility, but it is a new layer of understanding for me (HSCI20).

From this, we can see the ways that this instructor has experienced students' cognitive dissonance. Knowing how students have gotten to this point in their thinking clarifies the difficulties of reframing their understanding.

The reflections provided by these faculty illustrate the important pedagogical "connecting piece" that student development can provide. As instructors desire 
their students to engage deeply with the material, dialogue with peers, and think critically, it is vital to understand that such outcomes do not happen without intentional work on the instructor's part. Faculty wrote of "the connections between student development [and] teaching inclusively" (LAS172) by articulating:

Classroom climate is a major contributor to successful student classroom learning. The classroom climate needs to be inclusive so it is productive for all students. Professors should avoid climates that explicitly and implicitly marginalize a student or group of students. Professors should move to be more inclusive by developing or encouraging an implicitly centralizing climate. We need to be sure that stereotypes do not enter into the classroom either overtly or through more subtle activation of stereotypes as they negatively impact learning (CALS53).

As the data with this finding suggest, student development theories can be a useful pedagogical tool for faculty. Bearing in mind that so few faculty are taught these concepts in their doctoral education and socialization to the profession, one professor was particularly enthusiastic about student development theories. They stated, "The information about the developmental trajectory of students' social identities was fascinating. The whole chapter should be required reading for anyone teaching at university level" (LAS98). It appears as though the training sparked thinking about the knowledge that can be helpful to them and others entering higher education. One professor reflected, "It makes me think about how complex it is to be a high-quality educator, and that many of us were hired based on our research credentials with little formalized training in education and classroom activities and environment" (INTR117). Just as importantly, however, reflections have included how they might engage with these concepts in their future work, which is the subsequent finding.

\section{“Teaching inclusively is hard work!": Vulnerable Reflections}

It is clear to us the Inclusive Classroom Annual Training offered faculty an opportunity to take a moment to think about their teaching - what they do, what they think to do but fall short, and what they might want to do going forward. One professor stated that they "continue to make changes every semester to be aware of students needs especially in this fast paced, over-stimulated world in which we live" (DSN14). This person indicated they were:

reminded of many things I know but don't always actively employ in my teaching. It was an excellent review of what an inclusive classroom can be. I was humbled by the reminder of all of the changes that university students experience in their late adolescent/early adulthood and how that greatly impacts their view of the world and how to navigate within it (HSCI86).

This instructor's vulnerability is powerful as they describe how intensions and reality may not always match up in their courses: 
I had never really thought that one can be a well-intentioned instructor but not a truly inclusive one. I realized how usually the focus is to teach topics, deliver information, and not teach people, thinking about how everything happens in a social, emotional context and that doesn't go away when you enter a classroom (DSN3).

Another instructor extended this idea by noting their unique role in fostering productive learning environments, "Good intentions can have negative consequences. We need to create a learning environment where it is safe for the student be vulnerable and ask questions to fully engage with the content. We can help by modeling vulnerability" (INTR111). And this instructor seems to be developing a mantra when planning courses in the future, whereby they plan to:

consider my students as intellectual, social, and emotional beings. That my students are still developing in these areas, as well as their sense of identity. This idea will guide me in my effort to create course and classroom environment that supports student development and encourages learning (CALS39).

At the same time that these positive reflections are happening, one professor also pointed out a significant tension: good teaching is not always easy:

Teaching inclusively is hard work! It requires educators to be more "in-tune" with the needs of students and their ever-changing demographics. Things we did "yesterday" may no longer be relevant for today's learners. Inclusion is critical to the success of all students...something as simple as learning and using a student's name can be instrumental in their feelings of belonging and ultimately impact their retention and success (ENGR40).

As stated earlier, in addition to the student development peer-reviewed article, CELT also provided a handout within Module 3 (see Appendix A). Many faculty commented on their intentions to employ the strategies derived both from the article and the handout. For example, one professor plans on "engaging with students individually frequently in the semester to gain a better sense about what teaching methods work well for that person vs. those that do not" (CALS28). Another individual better recognized the "diversity of teaching styles I am needing to display to reach the students who may be at any stage of learning development" (VMED82). Many faculty commented on the Plus-Delta mid-semester feedback's effectiveness or their plans to utilize it in their classes. The Plus-Delta system allows for students to share directly with instructors (often anonymously) the things that are going well in the course (i.e., the plus) and the things that are not and might need to be changed (i.e., the delta). As one instructor indicated, they were "reminded of the importance of seeking feedback during the semester. I have not usually done this, since changing the kind of course material I teach (STEM content) is not really an option, but it may be that changing something about accessibility or assessment is possible" (INTR122). This passage illustrates how the Plus-Delta is a powerful strategy that allows the instructor to gain valuable feedback from students, make improvements, and communicate these course- and student-focused changes, leading to a more effective teaching and learning environment. 
The reflections within this manuscript represent most of our faculty, although there were outliers, as might be expected in training. It is to be noted that outlier comments tended to reflect the polarity in even needing any form of faculty development, specifically the disagreement with training focused on inclusivity.

\section{Discussion}

Three themes emerged from the assessment data of the module focused on student development theories. The first theme centers on the idea of compassionate teaching, noting that it is essential to teach students, not just content. The second theme indicates that faculty participants recognized that understanding student development theories could aid them in their and the university's goal of ensuring inclusive classroom environments. The third theme illustrates the faculty's vulnerable reflections as they consider their work of the past and future, noting that inclusive teaching is far from easy. In summary, one professor succinctly summarized the importance of student development theory on teaching and learning effectively:

I think reading these materials just reiterated that student development and course climate matter for student learning. When students feel safe and part of the discussion, they can learn. And maybe even more importantly, when students know that you care about them, they want to learn and do well (LAS188).

This study's contextual backdrop is Iowa State University's desire to foster a more inclusive campus, and learning environments are one integral piece of that. Our approach was to remind faculty participants that (traditional-aged) students are still developing intellectually and emotionally while in their classrooms. Upon turning 18 years old, students may be the age of majority but remain on a development journey that doesn't always feel like adulthood (Arnett, 2000). An individual's life story can impact development, making it easier for some to learn than others or for some students to learn one way versus another. Faculty were open about their realizations that understanding student development can help them create affirming learning environments. They also recognized the need for being intentional about this, rather than leaving learning to chance, which might be unintentionally marginalizing to some.

Based on our findings, we assert that faculty's knowledge of student development theory fosters inclusive teaching and learning on the college campus. Moreover, the connection among faculty self-reflection, empathy and compassion, and personal connections with students is essential for inclusive teaching. We offer a few recommendations below for consideration.

\section{Recommendations}

When CELT first began offering the mandatory inclusive classroom training, the module on student development theories was considered a foundational piece from 
which to springboard for a more in-depth discussion during the face-to-face session. We were surprised to read how few faculty knew about these theories and how integral the theories could be to faculty sense-making on developing and maintaining an inclusive classroom environment. It became clear that as a teaching and learning center, we needed to enhance our programming to include student development theory and work more closely with the student affairs educators whose "bread and butter" is student development. Further, while graduate education may not include teaching development, it confirmed to us as a center, the clear need and importance of providing effective teaching and learning training for new and joining faculty members to the university.

\section{Foster Academic Affairs - Student Affairs Partnerships}

CELT reports to the Senior Vice President and Provost's Office, a part of its academic affairs division. Similar to other land-grant institutions, there is an administrative division between academic and student affairs, with our center staff and faculty almost exclusively trained within academic disciplines. Whereas student affairs (SA) professionals are graduate-educated staff focused on students' holistic development, education, and well-being (ACPA/NASPA, 2010, 2015; Dungy \& Gordon, 2011; Reason \& Broido, 2011), our center's programming and staff expertise focuses nearly exclusively on the faculty or teaching side of the university.

As colleges and universities became larger, more diverse, and complex organizational systems in the twentieth century (Bastedo, 2012; Birnbaum, 1988; Dungy \& Gordon, 2011), the need for both academic and student affairs educators deepened with collaboration between the two groups lessening. We contend that it is necessary for teaching and learning centers to more actively cultivate programmatic partnerships between academic affairs (AA) and student affairs (SA). AA-SA collaborations have gained higher education scholars' attention in the last several decades, although the idea is not new (LePeau, 2015). The Student Personnel Point of View (American Council on Education [ACE], 1937) insisted on a symbiotic relationship between AA and SA from the very beginning, calling for "cooperative ventures" (p. 6) between the two groups of educators. Kezar and Lester (2009) suggest that a collaborative imperative still exists within the academy close to a century later, namely because "faculty in AA and practitioners in SA bring different areas of expertise to [an] issue" (LePeau, 2015, p. 97). While challenging to do well, such relationships provide opportunities and benefits to faculty, staff, students, and the institution (Kezar \& Lester, 2009; Kirby et al., 2019; Nesheim et al., 2007). AA-SA partnerships can take almost any form but are often specific programs to advance students' growth personally and academically. Examples might be learning communities or first-year programs with coursework and another component that focuses on another student outcome (e.g., institutional acclimation, career decisions; understanding social justice) (Nesheim et al., 2007; LePeau et al., 2018). However, when these program-courses do not explicitly have student affairs educators' participation, they cannot be described as an AA-SA partnership.

We would advocate for AA-SA partnerships that simultaneously capitalize on both educators' strengths. For example, in the near future, CELT will be working 
with the Academic Success Center on shared programming on teaching study skills for both a student and faculty audience. This open-and-dynamic programming could foster greater engagement between faculty and students within and outside of the classroom environment. Another example that would promote inclusion would be programming with leadership from a faculty developer and a SA educator holding divergent social identities. Such diverse representation in leadership sends a more welcoming message to participants of the programming.

\section{Validate Student Affairs Educators}

There are systematic ways in which administrative units and leadership can provide opportunities for faculty growth in teaching that move beyond individual faculty responsibility. Whether at the departmental or college levels, unit leadership can publicly validate student affairs educators as educators. Citing their knowledge of student development theory, leaders can elevate the value these individuals bring to the unit. Might there be an opportunity to include student affairs practitioners in a faculty meeting to brainstorm solutions to a departmental challenge? Leaders can go further by fostering strong collegial relationships between SA practitioners and faculty. For example, an instructor teaching first-semester students discusses with an SA educator about how best to embed students' epistemological development from "a state of simple, absolute certainty into a complex, evaluative system" (West, 2004 , p. 69). Such relationships can have mutually beneficial outcomes as well as promote student-centered learning within the classroom. There would be an added benefit of linking curricular and co-curricular learning together in a common space, promoting understanding in different ways, which is also inclusive.

\section{Provide Routine Departmental Reflection on Inclusive Teaching}

Department chairs can routinely reserve time, even a minimal 10-15 min at monthly mandatory faculty meetings, to discuss student development theories and resulting teaching strategies. This purposeful tactic can eliminate the "gosh, I never thought about it" mentality and provide faculty time to reflect on their course's successes and challenges. A seemingly simple prompt, such as "how can I make my classroom more inclusive?" can significantly impact student sense of belonging (Strayhorn, 2019). A cursory knowledge of student development theories would also benefit those faculty who advise student organizations as part of their service to the institution. Teaching awards and advisor-of-the-year awards can be an extrinsic value to this approach, not to mention publishing opportunities within journals that advance the scholarship of teaching and learning (SoTL).

\section{Make Student Development Theory Part of Faculty Development}

Those who work in faculty development can find ways to include student development theory as part of their knowledge with faculty. Campus teaching and learning centers can develop and provide workshops or webinars providing baseline information of student development theories. Higher-touch programming could include 
interactive workshops where faculty members brainstorm their newly-gained knowledge within their course syllabi, teaching strategies, evaluation practices, and curriculum design. Meaningful partnerships between teaching and learning centers and student affairs divisions can deepen the university-wide connections of these two often distinct units. Suggested ideas include representative committee and board involvement, once a semester (or more frequent) meetings where university-wide successes and challenges are shared, and joint development and branding of programming. Connections between units are often strengthened through personal relationships between staff members, deepening shared knowledge and practice.

\section{Limitations}

Our project enjoys the benefit of being possible only because this training was mandated for faculty by the administration. Without that, these data would not exist, and we consider that to be a strength of this study. However, like all assessments and research, our work comes with limitations. The data included in this paper come from a single, site-specific, land-grant, research extensive university, thus making our findings challenging to generalize into other college and university contexts. The findings also reflect a snapshot in time - faculty members' participation in the firstever mandatory Inclusive Classroom Annual Training. While we find these reflections deeply compelling, longitudinal study of faculty's use of student development theories and relationships with SA educators over time warrants further investigation at our institution and beyond. We recognize the value of follow-up with faculty on whether or not they implemented any of the strategies shared during the training; however, the current findings were interesting and important enough to allow CELT to think differently about the needs of faculty within our university. In the future, with thanks to added resources, we plan a multi-faceted approach to determine any pedagogical changes by interviewing faculty (individually or in focus groups) or asking them to complete a survey six months after the training to ascertain the most common teaching changes. Another option would be to utilize a document analysis method to examine syllabi before and after the training to see evidence of change. Finally, with any training feedback situation, response bias or acquiescence response (Costello \& Roodenburg, 2015) is a concern as participants tend to report what they assume wants to be heard rather than their honest thoughts.

\section{Conclusion}

Within this article, we used qualitative data from our campus Annual Inclusive Classroom Training. This data derived from the faculty reading an overview of student development theories. Faculty responses articulated the need to teach students rather than to teach content, and in so doing, creating inclusive learning spaces. Faculty participants provided a thoughtful reflection on their future actions around the intersection of inclusion and theory. The ideas articulated in this paper suggest ways of building faculty members' knowledge of student development theory as a 
pedagogical tool. We encourage readers to creatively think of ways to learn about and implement these theories in their work. Like the faculty in our training, we believe it will be enlightening.

\section{Appendix A: Inclusive Classroom Annual Training Worksheet}

\section{Strategies to Create an Inclusive Classroom}

Inclusive teaching includes course design, teaching strategies, and evaluation practices that cultivate a learning environment where all are treated equitably, have equal access to learning, and feel supported in their learning. Instructors can implement the strategies that best suit them, their disciplines, and their students.

This interactive document is for your use only. Mark strategies being used by clicking on the checkboxes; then, reflect on opportunities to promote inclusion by typing in the appropriate text boxes.

\section{Setting Guidelines to Establish a Positive Climate for Learning}

The Iowa State University Principles of Community (http://www.iastate.edu/principles) can serve as guidelines to facilitate engagement, to promote inclusivity, and to establish a positive climate for learning.

- Respect: We seek to foster an open-minded understanding among individuals, organizations and groups. We support this understanding through outreach, increasing opportunities for collaboration, formal education programs and strategies for resolving disagreement.

- Purpose: We are encouraged to be engaged in the university community. Thus, we strive to build a genuine community that promotes the advancement of knowledge, cooperation and leadership.

- Cooperation: We recognize that the mission of the university is enhanced when we work together to achieve the goals of the university. Therefore, we value each member of the Iowa State University community for their insights and efforts, collective and individual, to enhance the quality of campus life.

- Richness of Diversity: We recognize and cherish the richness of diversity in our university experience. Furthermore, we strive to increase the diversity of ideas, cultures and experiences throughout the university community.

- Freedom from Discrimination: We recognize that we must strive to overcome historical and divisive biases in our society. Therefore, we commit ourselves to create and maintain a community in which all can work together in an atmosphere free from discrimination, and to respond appropriately to all acts of discrimination. 
- Honest and Respectful Expression of Ideas: We affirm the right to and the importance of a free exchange of ideas at Iowa State University within the bounds of courtesy, sensitivity and respect. We work together to promote awareness of various ideas through education and constructive strategies to consider and engage in honest disagreements.

\section{Opportunities to Promote Inclusion in my Classroom}

How might you introduce and utilize the Principles of Community in your classroom?

\section{Course Design}

It is critical to examine not just the way we teach, but also our prep work before our classes begin. Consider how your learning objectives, activities, and assessments map onto the goals of your course. To give you a starting point, use CELT's Basic Course Design page (http://bit.ly/coursealignment).

\section{Syllabus}

Download and consider the use of CELT's Mindful and Learner-Centered Syllabus (PDF) (http://bit.ly/celtsyllabus).

Review the Interfaith Calendar website (http://www.interfaith-calendar.org/) for world religion sacred dates when scheduling major projects, presentations, exams, and course events. Example: Students fasting for Ramadan may choose not to participate in end-of-spring-semester celebrations involving food.

\section{Textbooks and Resources}

$\square$ Choose texts from authors of diverse backgrounds. Select content that engages a diversity of ideas and perspectives.

$\square$ Discuss contributions made to the field by historically underrepresented groups. Acknowledge the historical and contemporary absences of women and people of color when applicable.

$\square$ Examples that come quickly to us are often those that come from our own experiences. Avoid assuming your students share that experience. Notice if you base yours on regional knowledge that may be favored by one gender.

Provide access to supporting materials, such as illustrations, glossaries, and necessary background information based on prerequisites required for the course. 
Avoid highly idiomatic language and jargon. While the expressions may add interest, many students may miss an essential concept if the phrase is unfamiliar (e.g. "once in a blue moon," "between a rock and a hard place").

$\square$ Carefully consider how you use humor in your classes to ensure it degrades no one. Draw on humor and anecdotes relevant to the subject and sensitive to our campus's social and cultural diversity.

\section{Presenting Content}

Avoid phrases such as, "It's easy to see..." or "I'm sure the answer is obvious to all...". Phrases like these can implicitly discourage students who do not understand from asking questions.

$\square$ Ensure images and illustrations represent diverse appearances (e.g., genders, abilities, ages, etc.).

Use language that promotes a growth mindset. For example, rather than stating, "This course has supplemental instruction (SI) because I know women struggle with math," consider focusing on actions that would help every student, "I invite you all to attend the SI for more practice."

$\square$ Incorporate diverse student voices/perspectives/examples without stereotyping, spotlighting, or tokenizing.

Consider ways to engage students with the course content, with one another, and with you.

\section{Opportunities to Promote Inclusion in my Classroom}

In the first column, share your action item related to course design. List your next steps in the second column. Finally, consider sharing your efforts with a colleague, mentor, o r department chair/unit leadership.

\section{Teaching Strategies}

Inclusive teaching strategies refer to approaches that support meaningful and accessible learning for all students, promoting a sense of belonging, and encouraging student success.

\section{Building Community}

Create connections with your students and between your students using an ice breaker discussion forum. Choose a few topics and have your students select one 
to respond to - make sure you reply with your answer, too! Use the steps on the Create an Online Icebreaker Discussion page (https://bit.ly/celt-icebreak).

Course presence in Canvas is a part of all course delivery modes (face-to- face, hybrid, and online, https://bit.ly/isu-delivery) for fall 2020. An online presence in Canvas provides students with more flexibility. New ways to collaborate are directly related to how present and engaged both the instructor and the students are in the online classroom. When students are engaged, they tend to perform better. When students are actively involved in the material, they tend to process it more deeply, which leads to successful retention of the material. Learn more from the Engage Students Online page (https://bit.ly/celt-engage).

\section{Encourage Active Learning}

Chunk classtime into segments, such as 10-min lecture, 10-15 min of students engaged with active learning (discussion, problem-solving, low-stakes assessments), another 10-15 min lecture, and 5- minutes of student reflection to enhance engagement. When students feel engaged with the instructor, fellow students, and the subject, they are more likely to participate in class, feel valued, included, and respected.

Encourage full participation while being aware of differences that may influence students' responsiveness. Some students' silence may have learned in response to negative experiences with participation (e.g., being interrupted). In some cultures, asking questions is considered a rude interruption of class time. For example, consider asking students to write their responses rather than verbally report them, consider asking students to share their ideas with a classmate, and increase their wait time.

Invite students to complete projects on self-selected topics to draw on personal interests and relevance. Increase options for assignment format to allow students to choose oral presentation, research paper, and design project.

Invite students to co-design elements of classroom activities, for example, contribute to exam study guides.

Treat students as individuals whose identities are complex and unique. Example: Ask open-ended questions to solicit students' reports of their experiences without calling on a single student to speak for their race, gender, culture, etc.

\section{Group Work}

Intentionally create groups, asking students to join together on non-visible characteristics, i.e., birth month.

$\square$ When assigning group projects, ask students to rotate roles. The roles should be non-gender specific and of equal contribution. Example: Ensure those female group members are not always in secretarial/note-taking positions.

Provide multiple checkpoints to present opportunities for individual learning, accountability, and reflection. 


\section{Opportunities to Promote Inclusion in my Classroom}

In the first column, share your action item related to teaching strategies. List your next steps in the second column. Finally, consider sharing your efforts with a colleague, mentor, or department chair/unit leadership.

\section{Evaluation Practices}

All students need clear standards and evaluation criteria, straightforward comments on their work delivered with tact and empathy, and frequent feedback to change their learning strategies or seek additional help.

Provide frequent opportunities for informal assessment and feedback on progress.

$\square$ Share tools such as grading rubrics, in addition to assignment descriptions and criteria, to help a diverse community of learners clarify the requirements of an assignment.

$\square$ Consider whether the grading system you employ (for example, giving only a couple of high-stakes assignments) might demotivate students. Offer multiple lower-stakes opportunities to demonstrate knowledge and encourage students to develop growth mindsets (the belief that they can improve).

$\square$ Provide specific, actionable, and timely feedback to help students gauge their progress in the class.

\section{Opportunities to Promote Inclusion in my Classroom}

In the first column, share your action item related to evaluation practices. List your next steps in the second column. Finally, consider sharing your efforts with a colleague, mentor, or department chair/unit leadership. 


\section{Student Feedback}

Establish processes to receive anonymous feedback on the course climate and student learning. Make sure to review comments and report back to students at the next class session to validate their perspectives and improve the course to enhance student learning. Helpful tips on CELT's Plus/Delta webpage (http://bit. ly/isu-plusdelta).

The Plus/Delta is usually conducted in the first quarter of the class and includes four open-ended questions:

1. What is helping me to learn in this class?

2. What changes are needed in this course to improve learning?

3. What am I doing to improve my learning in the course?

4. What do I need to do to improve my learning in this course?

The Critical Incident Questionnaire (Brookfield, 2017) is done periodically and has five questions:

1. At what moment in class did you feel most engaged with what was happening?

2. At what moment in the class were you most distanced from what was happening?

3. What action that anyone (teacher or student) took this week did you find most affirming or helpful?

4. What action that anyone took this week did you find most puzzling or confusing?

5. What about the class this week surprised you the most? (This could be about your reactions to what went on, something that someone did, or anything else that occurs).

For Inclusive Classroom resources, ways to extend your learning, and references for this handout: Visit CELT's Creating an Inclusive Classroom webpage (http://bit.ly/celtinclusion) or use your camera app on your smart device and focus on the $Q R$ code, which will take you to the webpage.

Authors' Contributions PSH analyzed results, created conceptual framework,drafted manuscript; LB designed and facilitated training, peer-audited findings, edited manuscript; SBM designed and facilitated training, peer-audited findings, edited manuscript.

\section{Declarations}

Ethics Approval This work is exempt from IRB oversight, per our univerity's Office of Responsible Research (IRB 12-521). 


\section{References}

Abes, E. S. (2016). Situating paradigms in student development theory. New Directions for Student Services, 154, 9-16. https://doi.org/10.1002/ss.20171

ACPA, NASPA. (2010). 2015). ACPA/NASPA Professional competencies Rubrics.

Ambrose, S. A., Bridges, M. W., DiPietro, M., Lovett, M. C., \& Norman, M. K. (2010). Why do student development and course climate matter for student learning? In How learning works: Researchbased principles for smart teaching ( $7^{\text {th }}$ ed., pp. 153-187). Jossey Bass.

American Council on Education [ACE] Committee on Problems and Plans in Education. (1937). The student personnel point of view. American Council on Education studies, Series 1, Reports of Committee and Conferences, no. 3. American Council on Education.

Arnett, J. J. (2000). Emerging adulthood: A theory of development from the late teens through the twenties. American Psychologist, 55, 469-480.

Bastedo, M. N. (Ed.) (2012). The organization of higher education: Managing colleges for a new era. Johns Hopkins University Press.

Belenky, M. F., Clinchy, B. M., Goldberger, N. R., \& Tarule, J. M. (1986). Women's ways of knowing: The development of self, voices, and mind. Basic Books.

Birnbaum, R. (1988). How colleges work: The cybernetics of academic organization and leadership. Jossey Bass.

Brookfield, S. D. (2017). Becoming a critically reflective teacher (2nd ed.). Josey-Bass.

Butler, J. (2004). Undoing gender. Routledge.

Butler, J. (2018). Gender trouble (Special Indian Edition). Routledge. (Original work published in 1990).

Campus climate incidents. (n.d.). Iowa State University. https://www.campusclimate.iastate.edu/incid ents.

Cass, V. C. (1979). Homosexual identity formation: A theoretical model. Journal of Homosexuality, 4, 219-235.

Chickering, A. W. (1969). Education and identity. Jossey Bass.

Chickering, A. W. \& Reisser, L. (1993). Establishing identity. In A. W. Chickering and L. Reisser, Education and identity ( $2^{\text {nd }}$ ed., pp. 173-208). Jossey-Bass.

Costello, S., \& Roodenburg, J. (2015). Acquiescence response bias - Yeasaying and higher education. Australian Educational \& Developmental Psychologist, 32(2), 105-119. https://doi.org/10.1017/ edp. 2015.11

Creswell, J. W. (2014). Research design: Qualitative, quantitative, and mixed methods approaches $\left(4^{\text {th }}\right.$ ed.). Sage.

Cross, W. E., Jr. (1971). Toward a psychology of black liberation: The Negro-to-black conversion experience. Black World, 20(9), 13-27.

Cross, W. E., Jr. (1978). The Thomas and Cross models of psychological nigrescence: A review. Journal of Black Psychology, 5, 13-31.

Delgado, R. \& Stefancic, J. (2001). Critical race theory: An introduction (2 ${ }^{\text {nd }}$ ed.). New York University Press.

Dungy, G., \& Gordon, S. A. (2011). The development of student affairs. In J. H. Schuh, S. R. Jones S. R. Harper, and Associates (Eds.) Student Services: A handbook for the profession (5 ${ }^{\text {th }}$ ed., pp. 61-79). Jossey Bass.

Evans, N. J., Forney, D. S, Guido, F. M., Patton, L. D. \& Renn, K.A. (2010). Student Development in College: Theory, research and practice ( $2^{\text {nd }}$ ed.). Jossey-Bass.

Gardner, S. K. (2008). What's too much and what's too little? The process of becoming an independent researcher in doctoral education. Journal of Higher Education, 79, 326-350.

Haras, C., Taylor, S. C., Sorcinelli, M. D., \& von Hoene, L. (Eds.) (2017). Institutional commitment to teaching excellence: Assessing the impacts and outcomes of faculty development. American Council on Education.

Haraway, D. (2013). A cyborg manifesto: Science, technology, and socialist-feminism in the late twentieth century. In W. K. Kolmar \& F. Bartowski (Eds.), Feminist theory: A reader (4 ${ }^{\text {th }}$ ed., pp. $344-$ 354). McGraw Hill. (Original work published in 1985).

Harris, J. C. (2020). "Socialized into the field": Exploring how higher education and student affairs faculty members are socialized to teach student development theory. Journal of College Student Development, 61(1), 1-17. https://doi.org/10.1353/csd.2020.0000

Helms, J. E. (Ed.) (1993). Black and white racial identity: Theory, research, and practice. Praeger. 
Iowa State University (2020). 2019-2020 Fact Book. https://www.ir.iastate.edu/factbook/2019-2020.

Iowa State University (2021). Enrollment counts [Unpublished raw data].

Jagose, A. (1996). Queer theory: An introduction. New York University Press.

Jones, S. R., \& McEwen, M. K. (2000). A conceptual model of multiple dimensions of identity. Journal of College Student Development, 41, 405-413.

Jones, S. R., \& Stewart, D.-L. (2016). Evolution of student development theory. New Directions for Student Services, 154, 17-28. https://doi.org/10.1002/ss.20172

Kezar, A. J., \& Lester, J. (2009) Organizing higher education for collaboration: A guide for campus leaders. Jossey-Bass.

Kirby, M. D., Fitzgerald, F. M., Marable, R., Eason, A. L., Nicholson, S., \& Arroyo, A. T. (2019). Student learning communities: An avenue to academic affairs and student affairs partnerships at Historically Black Colleges and Universities. New Directions for Student Services, 167, 11-21. https://doi.org/ $10.1002 /$ ss. 20317

Kirwan Institute for the Study of Race and Ethnicity (2015). State of the Science: Implicit Bias Review 2015. Retrieved from http://kirwaninstitute.osu.edu/wp-content/uploads/2015/05/2015-kirwanimplicit-bias.pdf

Klein, F., Sepekoff, B., \& Wolf, T. J. (1985). Sexual orientation: A multi-variable dynamic process. Journal of Homosexuality, 11(1-2), 35-49. https://doi.org/10.1300/J082v11n01_04

Kohlberg, L. (1976). Moral stages and moralization: The cognitive-developmental approach. In T. Lickona (Ed.) Moral development and behavior: Theory, research, and social issues (pp. 31-53). Holt.

LePeau, L. (2015). A grounded theory of academic affairs and student affairs partnerships for diversity and inclusion aims. The Review of Higher Education, 39(1), 97-122. https://doi.org/10.1353/rhe. 2015.0044

LePeau, L. A., Hurtado, S. S., \& Davis, R. J. (2018). What institutional websites reveal about diversityrelated partnerships between academic and student affairs. Innovative Higher Education, 43, 125142. https://doi.org/10.1007/s10755-0179412-0.

Long, D. (2012). Theories and models of student development. In L. J. Hinchliffe \& M. A. Wong (Eds.), Environments for student growth and development: Librarians and student affairs in collaboration (pp. 41-55). Association of College \& Research Libraries.

McRuer, R. (2006). Crip theory: Cultural signs of queerness and disability. New York University Press.

Mendoza, P., \& Gardner, S. K. (2010). On becoming a scholar: Socialization and development in doctoral education. Stylus.

Meyers, S., Rowell, K., Wells, M., \& Smith, B. C. (2019). Teacher empathy: A model of empathy for teaching for student success. College Teaching, 67(3), 160-168. https://doi.org/10.1080/87567555. 2019.1579699

Nesheim, B. E., Guentzel, M. J., Kellogg, A. H., McDonald, W. M., Wells, C. A., \& Whitt, E. J. (2007). Outcomes for students of student affairs-academic affairs partnership programs. Journal of College Student Development, 48(4), 435-454. https://doi.org/10.1353/csd.2007.0041

Nicolazzo, Z. (2016, March 19). Taking a break from student development theory. Trans* Resilience Blog. Retrieved from https://znicolazzo.weebly.com/trans-resilience-blog/archives/03-2016.

Perry, W. (1968) Forms of intellectual and ethical development in the college years: A scheme. Holt, Rinehart \& Winston.

Perry, W. (1981). Cognitive and ethical growth: The making of meaning. In Chickering and Associates, The Modern American College (pp. 76-116). Jossey-Bass.

Phinney, J. S. (1993). A three-stage model of ethnic identity development in adolescence. In M. E. Bernal \& G. P. Knight (Eds.) Ethnic identity: Formation and transmission among Hispanics and other minorities (pp. 61-79). State University of New York Press.

Reason, R. D., \& Broido, E. M. (2011). Philosophies and values. In J. H. Schuh, S. R. Jones S. R. Harper, and Associates (Eds.) Student Services: A handbook for the profession ( $5^{\text {th }}$ ed., pp. 80-95). Jossey Bass.

Reason, R. D., \& Kimball, E. W. (2012). A new theory-to-practice model for student affairs: Integrating scholarship, context, and reflection. Journal of Student Affairs Research and Practice, 49(4), $359-376$.

Saldaña, J. (2016). The coding manual for qualitative researchers $\left(3^{\text {rd }}\right.$ ed.). Sage.

Sanford, N. (1966). Self and society. Atherton Press.

Selingo, J. J. (2018). The new generation of students: How colleges can recruit, teach, and serve Gen Z. The Chronicle of Higher Education. 
Starck, J. G., Riddle, T., Sinclair, S., \& Warikoo, N. (2020, April 14). Teachers are people too: Examining the racial bias of teachers compared to other American adults. Educational Researcher, 49(1), 273-284.

Strayhorn, T. L. (2019). College students' sense of belonging: A key to educational success for all students. Routledge.

Talburt, S. (2011). Queer theory. In B. J. Bank (Ed.), Gender and higher education (pp. 86-93). John Hopkins University Press.

Titchosky, T. (2011). The question of access: Disability, space, and meaning. University of Toronto Press.

West, E. J. (2004). Perry's legacy: Models of epistemological development. Journal of Adult Development, 11(2), 61-70.

Publisher's Note Springer Nature remains neutral with regard to jurisdictional claims in published maps and institutional affiliations. 